\title{
The Past as the Key for the Future: What Does (Medieval) Literature Mean Today in the Twenty-First Century?
}

\begin{abstract}
By Albrecht Classen*
The Humanities are increasingly challenged by the fields of Science, Medicine, and Business, but people desperately need to understand their fundamental human side in order to cope constructively in this world. Continuing previous explorations of this large topic, this paper focuses, once again, on the questions what history really means for us today, how literary narratives allow us to ruminate on the human condition, both materially and spiritually, and how we can profit from the philosophical insights developed by Karl Jaspers in his reflections on Vom Ursprung und Ziel der Geschichte (1949). Despite, or just because of the rapidly expanding digitization of nearly every aspect of human existence, the Humanities continue to be of essential relevance in everything we do, study, embrace, or pursue in our lives.
\end{abstract}

Keywords: Humanities, History, Literature, Relevance, Karl Jaspers, Medieval Studies, Philosophy, Religion

\section{The Meaning of History for Us Today}

Every historian is only too well aware about the fact that history as we know it is the result of our modern research into the past. If we did not care about it, it would simply disappear from our view and our awareness. In a way, we create that past through the application of our lenses and by pursuing our research interests with which we turn to older sources and documents. One recent example proves to be the history of the Avars, a nomadic people who lived in the steppes of the Carpathian Basin from the sixth to the ninth centuries and have been mostly ignored by research until only recently, especially because they left practically no written documents. Now, together with the significant help of archeologists, historians such as Walter Pohl have finally succeeded in bringing back to life what we can tell regarding the Avars, and future research promises to yield even more results (Pohl 2018). Of course, this does not yet tell us why the world of the Avars would matter to us today, and by the same token, the history of the Celts, the Lombards, the Visigoths, or the Vandals. Obviously, the weights given to one people or one culture, to that ideology or another, can easily shift, from generation to generation, much depending on our modern interests and needs for cultural identity. Significantly, for instance, Eurocentrism is currently being replaced by globalism, and the public debate concerns deeply what constitutes the relevance of culture, history, and the arts in the present world (Sharman 2019) ${ }^{1}$.

\footnotetext{
*University Distinguished Professor, Department of German Studies, The University of Arizona, USA.

${ }^{1}$ Sharman argues, for instance, that the rise of Europe to the level of an imperialist and colonizing superpower in the late eighteenth and nineteenth centuries was only a temporary experience,
} 
Some historical periods and its documents are now the center of attention that have been ignored before, as illustrated, for example, by the enormous growth in interest dedicated to medieval women's literature; other generations of (male) scholars cared very little about that. Another issue, this one being of a very political nature, now proves to be the very serious efforts by the Polish government to deny any Polish responsibility for the Holocaust by means of legal measures, which has caused serious tensions between Poland and Israel (Polonsky 1990, Wolff-Powęska and Forecki 2013, Bikont 2015, Dreifuss 2017)2. Our relationship with the past casts long shadows on our individual and collective identity.

\section{The Role of the Humanities Today}

This paper will examine the relevance of medieval history and literature for our modern discourse regarding the meaning life, both from a very pragmatic and a philosophical perspectives. To help us understand the larger context better, here I will draw strongly on philosophical insights developed by Karl Jaspers and combine those with reflections on a wide range of medieval narratives addressing religious/spiritual, political, economic, gender issues that continue to be of great relevance for us.

Modern research constantly re-discovers poets and poems from the premodern time, as documented by the ongoing efforts to edit and translate texts from the past and thus to make them more available for us today (Busch and Reich 2014). None of that is simply l'art pour l'art; instead, the exploration of the past is always intimately tied into contemporary political, ideological interests (Simonton 1994, Jenkins 1999). Deliberately putting a lid on history thereby constitutes a specific strategy most people might not even be aware of, especially when certain memories are supposed to be repressed, as we see it happening right now in 2018 and 2019 with various eastern European countries making strong attempts to distance themselves entirely from the Holocaust and thereby try to assume the position that they had been nothing but victims of Nazi violence. This is a political debate, just as the argument pertaining to the genocide of the Armenians by the Turks in 1915, which the present Turkish government denies. We could also point out the ominous parallels between Hitler's power grab after the arson of the Reichstag on February 27, 1933, and threats by the US government in Feb. 2019 to declare a state of emergency, giving the president extraordinary powers, allegedly because of a national crisis at the southern border. Significantly, we can and must go even further in history to recognize the engines that drove humanity and thereby created the groundwork or the cultural soil from which we then emerged. In short, the

while the true superpowers in the East, such as China, are currently regaining their traditional and common world position.

${ }^{2}$ For the latest situation, see Friedberg E (2018, February 6) "The Truth About Poland's Role in the Holocaust". The Atlantic. Retrieved from https://ces.to/poewDm; and https://ces.to/GIcTY0 (last accessed on May 31, 2019). 
Middle Ages are right with us, and so the voices of medieval poets in many intriguing fashions.

\section{Past and Present: How Do We Face the Tomorrow?}

To refocus our investigation here, all of us working in the profession of education are constantly challenged by the universal and always relevant question what the relevance of history or the humanities might be, especially when tomorrow's challenges are already knocking on our doors. The common response relies on the observation by Jorge (George) Santayana (1863-1952) (Farre 1953), which is by now widely disseminated and has almost fallen into the trap of being nothing but a platitude or a cliché: "Those who cannot remember the past are condemned to repeat it" (Wippel 2011, Krüger 2005, Hunt 2018, Wineburg 2018). He also commented about philosophy and the reverse ranking of the major contributors, mostly dismissing the moderns in favor of the ancients: "...the progress of philosophy has not been of such a sort that the latest philosophers are the best: it is quite the other way...the later we come down in the history of philosophy the less important philosophy becomes, and the less true in fundamental matters"3.

However, this is not a paper about the philosophy of history, but about the history of our culture and its meaning for us today. The same question, after all, can be raised regarding the history of literature, especially medieval texts, and why they would matter for us today. Or, we could inquire about the meaning of the history of art, architecture, philosophy, religion, technology, sciences, or medicine in the present day and age. The surprisingly simple, perhaps naive answer would be: everything we do or deal with has a past and lives from its own history, and there are no firm rules as to the value or validity of modern contributions versus ancient or medieval ones. Instead, we live in a long concatenation of ideas that all deserve to be recognized, especially because many have proven their timeless relevance, some submerging, others emerging, in direct response to our contemporary discourse. Nevertheless, this claim regarding the relevance of historical documents (literature, chronicles, art works, etc.) for today needs to be fleshed out, expanded, and illustrated further. The investigation of the historical dimensions of the Humanities forces us, ultimately, to reflect upon the meaning of our entire field, an enterprise which is not new at all, but one that certainly needs to be carried out over and over again because it constitutes the fundamental epistemology of our cultural identity as Humanities scholars (Verene 2018, Bess and Pasuka 2018) ${ }^{4}$.

Many poets and intellectuals from antiquity to the present have reiterated this idea as formulated by Santayana, regularly lamenting people's disinterest in the past, although it is the ground from which we all have grown ${ }^{5}$. However,

\footnotetext{
${ }^{3}$ Quoted from Flamm MC “George Santayana (1863-1952)”. Internet Encyclopedia of Philosophy. Retrieved from https://ces.to/DAbyJ1.

${ }^{4}$ See also the impassionate appeal by Nussbaum (2012).

${ }^{5}$ For a good selection of relevant statements, see, for instance https://ces.to/aeO019.
} 
today we live in a very fast age, with changes happening around us all the time which less and less people can really grasp or handle properly, if at all. Digitization, robotization, and thus the emergence of Industry 4.0 place great demands on the young generation to prepare itself for the new challenges and thus to gain jobs and the ability to maintain their own lives. Newspapers witness a steady decline of subscriptions; libraries are turning increasingly into media or community centers neglecting their traditional purposes and functions to make available books, i.e., printed material, while archives are mostly neglected by the younger generation. At the same time, the flood of predigested data drawn from the internet occupies all our minds, blocking us from pursuing free thinking and deep cultural awareness Instead of growing into new independence and global perspectives, the current readership is incrementally becoming dependent and subject to digital controls.

Not surprisingly, this forces us to probe, once again, where all this leaves the Humanities, or the Social Sciences, that is, every subject matter that does not seem to be directly related to the practicalities of professional life outside of the academia? To raise this question opens a Pandora's box that many scholars, politicians, writers, and artists have addressed already, both in the past and in recent years ${ }^{6}$. Most of them have reached the consensus, broadly speaking, that our lives are not only determined by material conditions; instead, we are, as human beings, spiritual, cultural, intellectual, and emotional as well, and each area needs to be addressed as much as possible in our existence if we want to thrive and achieve the highest potential possible.

There is no price tag on all those dimensions, structures, ideals, and values, but I believe that we can all agree on the supreme importance of those intangibles in our existence, irrespective of our cultural, ethnic, linguistic, or political backgrounds. They are intangibles, yet they are very real as well, whether it is love, the search for God, friendship, the value of beauty, the meaning of life, or death.

\section{Outline of the Argument}

One major contributor to the discourse alluded to here was the German philosopher Karl Jaspers, who endeavored to come to terms with this issue in his famous study Vom Ursprung und Ziel der Geschichte (On the Origin and Goal of History) (1949); written after the horrible experiences of the Second World War and the Holocaust which came very close to home in his case, with his wife being Jewish. Jaspers was also a witness of the new development of the atom bomb and modern technology, though he was not yet aware of the computer and the Internet. We will have a great opportunity to draw some insights from his reflections and to apply those to the more specific inquiry about the relevance and meaning of pre-modern literature in the twenty-first century. While there have been many other philosophers, such as Santayana,

${ }^{6}$ For a very recent response to this question, see Hunt (2018), and MacMullen (2014). The list of relevant studies both in history and in literature, in art history and social studies is legion. 
who examined the same issue in their own way, Jaspers's comments have not yet been considered closely enough in our present context.

This paper thus intends to reflect critically once again on the deep meaning of the past for the present and the future, the perennial challenge for every individual here on earth because we constantly move forward, forget the yesterday, and are thus constantly in danger of ignoring our own background, our past, our traditions, our values, our ethics, and our ideals. We stand to profit from Jasper's insights to this larger discourse in a unique fashion, but first I will examine more concrete examples from medieval history, philosophy, and poetry. In particular, today the relevance of literature is at stake, considering the constant calls for STEM at schools and universities to the disadvantage of the liberal arts, including the study of foreign languages. However, this is not a new phenomenon; instead, already since antiquity intellectuals felt the need to defend poetry and the arts at large. Moreover, much recent research has confirmed that graduates in the Humanities are not really worse off than those in fields such as Engineering. The Liberal Arts continue to be of great significance and are essential for the growth of our society in a meaningful way, and this in every sector of our economy, education, political system, the medical field, the arts, and also sciences ${ }^{7}$.

This study consists of three parts closely interwoven with each other. First, I will revisit the broader field of Medieval Studies to gain a better understanding of how we can explain to our present student generation and the public why the past matters so much, especially the Middle Ages as the last most impactful cultural period determining the rise of the western world ca. thousand five years ago after the fall of the western Roman empire. Second, looking briefly at a number of specific examples from medieval literature, I want to outline how we can approach this difficult issue and translate it into a productive tool for many academic and non-academic purposes. Third, drawing from some philosophical reflections by Karl Jaspers and other cultural critics, I will examine the meaning of the past for us today in detail, exploring why history is relevant for us in our present day and age in a significant manner because we remember so many mistakes, errors, faults, shortcomings, failures, and even crimes committed by our predecessors which we really want to avoid in order to move forward as a civilized society. However, memory is not necessarily a negative; on the contrary, remembering allows us to think critically about this world and our own position here on earth, not blindly assuming responsibility for our forefathers, but keeping in mind what they have done, for better or worse. Without the archaeology of knowledge, as Michel Foucault had called it, we are in danger of not understanding anything in our present condition. After all, major intellectual achievements and ideas created

\footnotetext{
${ }^{7}$ As to a direct response to the challenges posed by STEM against the Humanities, see Dafoe (2016) and Classen (2018a). For the long tradition of intellectuals and writers rallying to the defense of the Humanities (poetry, literature, the arts, etc.), see the very useful collection of relevant excerpts (Davis and Finke 1989). For most recent data regarding career opportunities for graduates in the Humanities, see the report by Catharina B. Hill and Elizabeth Davidson Pisacreta "The Economic Benefits and Costs of a Liberal Arts Education". The Andrew W. Mellon Foundation Reports. Retrieved from https://ces.to/1HU60L.
} 
in the past continue to have a huge impact on us today and guide us toward the future, like a pilot light in the darkness of life. In Foucault's words,

the analysis of the archive, then, involves a privileged region: at once close to us, and different from our present existence, it is the border of time that surrounds our presence, which overhangs it, and which indicates it in its otherness; it is that which, outside ourselves, delimits us. The description of the archive deploys its possibilities (and the mastery of its possibilities) on the basis of the very discourses that have just ceased to be ours; its threshold of existence is established by the discontinuity that separates us from what we can no longer say, and from that which falls outside our discursive practice (Foucault 1972: 130-131).

My favorite metaphor for history and human culture is the tree. Every biologist will confirm that all parts of a tree are essential in guaranteeing that this living creature can exist and survive. Without the leaves up to the very treetop, there would not be photosynthesis, evaporation of water, and subsequently no capillary movement or transportation of water from the roots to the very extremities of the tree. Only a close cooperation of all parts makes it possible for the tree to thrive and to achieve its full potential. This applies, of course, to every other living creature as well, which hence means that we must always consider two principal vectors, the horizontal (present) and the vertical (past, present, and future). In human terms, this means the central importance of connectivity, as Brené Brown (2017) has stated famously ${ }^{8}$, but not only in contemporary terms. If we understand and appreciate the history and culture of our neighbors (in the village, in the town, in the state, in the country, in the world), we build the deep roots of connectivity that are not only two-dimensional, but essentially tridimensional. We must move beyond the tiny dots in the endless curve of life and reach out for the circle that constitutes existence in a holistic fashion, irrespective of religious or cultural differences. That circle, or tree, draws from many different directions and constitutes the true world wide web, consisting of memory, the archive, the human drive toward the good (Boethius), knowledge about past and present, and the love for our neighbors.

\section{Part I: Humanities, Literature, the Middle Ages}

Human existence is, in a very meaningful way, determined by narratives; we are constantly telling our own history and create it by means of narration that always contains many different threads, going sideways (present) and downwards (past). Autobiographies mirror ourselves, but the text-producing

\footnotetext{
${ }^{8}$ She argues, here quoting from an online summary of the book, "True belonging requires us to believe in and belong to ourselves so fully that we can find sacredness both in being a part of something and in standing alone when necessary. But in a culture that's rife with perfectionism and pleasing, and with the erosion of civility, it's easy to stay quiet, hide in our ideological bunkers, or fit in rather than show up as our true selves and brave the wilderness of uncertainty and criticism. But true belonging is not something we negotiate or accomplish with others; it's a daily practice that demands integrity and authenticity. It's a personal commitment that we carry in our hearts".
} 
individual has always been in the intriguing position of determining life through its own perspective, which in turn is determined by the words coined by the individual in its interchanges with the physical dimension outside of the self (Bruner 1988, Hatch and Wisniewski 1995, Brockmeier and Carbaugh 2001, An et al. 2018). The chorus of voices is therefore rather expansive and difficult to handle, and yet each voice has the potential of sharing valuable information or data, conveying ideals, values, and concepts. But we also must keep in mind what Plato had allegedly formulated a long time ago: "Wise men speak because they have something to say; Fools because they have to say something".

As in the case of Boccaccio's Decameron (ca. 1350), for instance, or Chaucer's Canterbury Tales (ca. 1400), people develop and grow in communities, they depend on sharing, and thrive on the experiences passed on to them by those voices from the past. Reading literature, for instance, thus proves to be a process of connecting ourselves with our roots, or other roots, and developing new trunks and stems for future leaves and flowers. I am, however, not concerned with a limited list of individual texts, or specific languages, but with the fundamental value of the literary discourse in its cultural-historical context, which is tantamount to a forest of trees, each of which has its own value, though they all resemble each other in its fundamental composite parts.

Before we proceed, we must also make a distinction between history and cultural history. Traditional study of history focused on wars, rulers, feudal structures, urban dwellings, economic conditions, epidemics, religious conflicts, and other major developments. Here I am concerned, by contrast, with cultural history, also with the history of mentality, and the history of everyday life, as commonly expressed by literary narratives, written or formulated orally (Dinzelbacher 1993/2008). More precisely, the focus here will rest on the meaning of literary and philosophical texts as historical documents and the question how we can approach them today in a way that makes sense for modern readers and convinces them that they can and really should engage with them intensely because they shed important light on present-day, or universal, issues of great significance. The subsequent reflections are to be understand as representative of all efforts to come to terms with our past and to figure out a pathway toward the future.

Let us thus assume that literature is of relevance, globally, irrespective of its origin and date, and irrespective of whether it was recorded in writing or has been preserved orally only. In this paper, however, I am not concerned with the age-old debates regarding the canon versus trivial texts (Classen 1993, Classen 2011a, Classen 2013a, Bloom 1994, Sinaiko 1998) ${ }^{9}$, and I do not want to enter into the abyss of endless discussions about whether the Humanities have any value today. Of course, they do, very much so, maybe even more so than in the past, but they face difficult times today because of enormous economic pressures on our young student generation.

\footnotetext{
${ }^{9}$ The literature on this issue is legion; the discussion of the canon and its meaning involves race, sexism, misogyny, power structures, and many other political issues both in the past and the present.
} 
However, as many scholars and journalists have noted with a strong emphasis, a degree in the Humanities continues to be of great relevance and prepares our graduates in rather surprising fashions for their professional lives, even if they might not apply directly what they have learned through the study of Beowulf, the Nibelungenlied, Boccaccio, Shakespeare, Aphra Behn, Molière, Goethe, Turgenev, Faulkner, Virginia Woolf, Thomas Mann, Hermann Hesse, Christa Wolf, and many others. In fact, considering most recent challenges and explorations, the Humanities and STEM are not that far apart from each other, especially because the study of literature makes possible the exploration of the widest range of human experiences and concerns, which in turn can be applied to practical aspects in the Sciences, Medicine, Politics, and the Economy (Pleshakova 2009, Gleason 2018, Bradley 2018). By the same token, those working in the Humanities are also called upon to understand the Sciences and Medicine as much as possible because they are an intimate component of all human life. We can also simply add that the very fact that we are human beings and define ourselves through culture and selfhood, for instance, confirms the centrality of our subject matter because it allows us to return to our own identity and to explore who we are and what constitutes our spiritual and material frameworks (Sorabji 2006, Schiffrin et al. 2010).

In a number of different articles, I have already discussed at length how we could make medieval literature relevant for modern readers, or specifically, how we as teachers and scholars can bring to light what messages in many different texts in the pre-modern world continue to speak to us because of their timeless relevance (Classen 2013b, Classen 2015a, Classen 2016a, Classen 2018b). There are countless opportunities to examine, for instance, heroic literature as a medium to explore such universal issues such as honor, treason, murder, war, betrayal, loyalty, individuality, and ultimately, leadership, integrity, and role models (Classen 2000, Classen 2011b). If we are interested in investigating the huge discourse on toleration and tolerance, for instance, we find numerous examples already in high and late medieval literature with unique inclusive perspectives and will find ourselves in the surprising company of pleasantly startlingly open-minded writers, philosophers, and even theologians (Classen 2018c).

Gender issues, marriage, sexuality, friendship, and many other topics were of central concern for medieval and early modern theologians, philosophers, and poets, and they certainly continue to be so for us today (Blažek 2018). There is no shortage of relevant medieval texts dealing with foreigners, monsters, and strangers. The issues of multilingualism and multiculturality find rich reflections as well (Armstrong and Strietman 2017, Classen Forthcominga). World exploration, economic exchanges, scientific and medical learning, translation issues, homosexuality, and also the close interaction between humans and their natural environment were all well represented in pre-modern literature, as modern research has richly documented ${ }^{10}$. Even the relationship between people and robots was already a significant topic in the pre-modern world (Truitt 2015). The issue of war and peace has been discussed not only in

\footnotetext{
${ }^{10}$ Instead of referring to many different studies, see the contributions to Classen (2015b).
} 
the twentieth and twenty-first centuries, but the relevant discourse can be traced back to a very old tradition grounded in the Middle Ages, but also in antiquity (Jansen 2017, Classen Forthcoming-b).

Our contemporary philosophical investigations are so deeply determined by their historical roots that we do not even need to question the relevance of the pre-modern world in this academic discipline (von Kutschera 2019). The same applies to religion, whether Christianity, Judaism, or Islam (in the Western world and the Middle East), which is intimately connected with literature. In fact, we could read virtually all major religious texts as literature, and much of our literature through the lens of religion (Lang 2019). In other words, all our basic human needs for spirituality find full expressions in literary texts, whether we think of the parables in the New Testament, the medieval mystical accounts by individuals such as Hildegard of Bingen or Mechthild of Magdeburg, the miracle stories by Caesarius of Heisterbach, the esoteric reflections by Master Eckhart, Martin Luther's hymns and table talks, and countless other examples.

\section{Religion and the Human Quest for Spirituality}

Religion and literature are intimately tied in with each other and contribute to the expansion of the spiritual dimension within human life. Most if not all religious authors convey profound, often ineffable and apophatic messages, which members of secular societies tend to ignore or reject, although those very messages continue to be there waiting for us throughout time. While there might be severe tensions between representatives of different faiths, each rejecting the holy scriptures held dear by the others, religious poetry, for instance, whether by Rumi, Maimonides, Heinrich von Meissen, Yehudah Halevi, Catharina Regina von Greiffenberg, Angelus Silesius, or Emily Dickinson has always enjoyed a different status, addressing universal religious experiences not bound by specific church teachings or faith communities.

The idea of the human quest, whether formulated in a narrowly religious fashion, or in literary terms, has permeated all literary cultures and constitutes to a large extent the very nature of literature. Quite parallel to the biblical accounts, Bede's Ecclesiastical History, Tundale the Knight's Visios, the many different medieval Grail quest narratives, Gottfried of Strasbourg's Tristan, Dante's Divina commedia, William Langland's Piers Plowman, Edmund Spenser's Faerie Queene, or John Milton's Paradise Lost, to name a few medieval and early modern texts, have all followed the same path and experimented with the model of catabasis, outlining the individual's effort to survive the deep fall into hell and to climb back not only to earth, but to reach Paradise as well (Tormey 2018).

The protagonist often cannot achieve this goal without help, whether it is Virgil who appears in Inferno to support and guide Dante, or whether it is a secret society that appears in the background steering the protagonist onto the right path and providing the necessary encouragement for idealism to come to full fruition, such as in Johann Valentin Andreae's Christianopolis from 1619 
(Brecht 2008, Comenius 1992, Murphy 1995). The same phenomenon emerges in Wolfgang Amadeus Mozart's Magic Flute from 1791 and then in Johann Wolfgang Goethe's Willhelm Meister's Lehrjahre from 1795/1796, where each time a group of wise and old people observes, tests, and assists the hero on his or her path toward a spiritual goal (Classen 2012). Even Thomas Mann (The Magic Mountain, 1924) and Hermann Hesse (The Glass Bead Game, 1943) subscribed to that ideal, which medieval poets expressed most vividly in the various Grail romances. The quest is ongoing, and we as people continue to stumble through our lives, not knowing much about our purposes and directions. If we look only forward, we lose the orientation; if we look only backwards, we cannot move forward.

This takes us back to the same metaphor mentioned above, the tree, which represents all life, with the roots communicating with the treetop, the branches with the trunk, the wood with the leaves, etc. Existence has much to do with communication, and not just among equal elements, but across the spectrum of individual creatures, which often requires translation. This communication, however, does not simply aim for the future, but is deeply based on the narrative past upon which stories continuously grow that will be told tomorrow.

For instance, although we still cannot quite identify the exact stepping stones that connect the Arabian stories of One Thousand and One Nights with the world of medieval and early modern story telling ("The Arabian Nights" 2010, Ouyang and van Gelder 2005, David 1992, Sallis 1999) ${ }^{11}$-Petrus Alfonsi's Disciplina clericalis, the anonymous Gesta Romanorum, Caesarius of Heisterbach's Dialogus miraculorum, Boccaccio's Decameron, Chaucer's Canterbury Tales, the anonymous Cent Nouvelles Nouvelles, and Marguerite de Navarre's Heptaméron, here disregarding many other medieval and early modern anthologies - we are on solid ground when we consider the global network of storytellers. Moreover, the ancient Indian Panchatantra, which the medieval Europeans learned to appreciate in the Latin and then many different vernacular versions under the title Liber Kelilae et Dimnae by Johan of Capua, otherwise known as the Directorium humanae vitae, not to forget the collection of tales known as The Seven Wise Men, all demonstrate the shared interest in and concern with the universal human need to learn from past experiences and to gain insight into many different types of human behavior, bad and good (Clements and Gibaldi 1977, Chinca et al. 2006, Grubmüller 2006).

Despite the vast number of available stories, which all differ, at least to some extent, from each other in theme, content, moral lessons, and values, storytellers have always provided the same narrative material in which the audience (readers or listeners) could mirror itself and learn from. What is there to talk about, both yesterday and today, and what will we talk about tomorrow? There are not many issues that deserve our attention, whether in religious or in secular texts. Considering the situation in world literature, we observe the obvious. Writers and poets have always addressed the quest for the self, the search for the meaning of life, and for the purpose of death, the quest for God,

${ }^{11}$ Both here and in countless other short narratives, the theme of sexuality dominates; see Ghanim (2018). 
for one's own identity, the exploration of honor and its opposite (shamefulness, failure, shortcoming, etc.), love, sexuality, and maybe also the experience of beauty and joy. Hence, it does not come as a surprise that many scholars have identified the Bible as literature; and mutatis mutandis this also applies to the other holy scriptures, such as the Torah and the Koran (Gottcent 1979, Clark Kee 1997, Knauer 1997, McAfee 1998, Norton 2000). After all, there are no patent answers to any of the myriad problems we all face here in our lives. On the contrary, there are countless uncertainties, and fears and worries commonly vex us as soon as our reflective capacities have set in and confront us with the uncanny limits of our existence. No amount of money and no worldly powers can save or protect us from death, from sickness, from lack of friends, from loneliness, from hopelessness, and from desperation.

Both Boethius (d. 525) and Johannes von Tepl (d. ca. 1415) knew that very intimately when they composed the Consolation of Philosophy and The Plowman and Death respectively. Both faced certain death (imminent in Boethius's case; the loss of the own wife in Johannes's case), suffering, desperation, and yet both pulled themselves up from their sorrow and deep frustration by writing their narratives in which they both gained insight into the true path toward happiness and beauty, finding themselves at the end not in the doldrums of death and hell, but on their path toward the goodness, the summum bonum. They were followed by many early modern and modern writers who also explored, in their own ways and means, how to make sense out of life and to lay the groundwork for future readers/listeners to forge their own path toward the future.

Of course, each period and each era faces its own problems and challenges, and yet each generation produces its own literary voices that address them and help us to come to terms with the fundamental issues, each time picking up there were a predecessor has left off, or resuming the same discourse as pursued by the various poets in the past. We will be required each time to translate some of the messages into a language or imagery that is understandable for us today, thus building connections between us today and our predecessors in previous centuries. Nevertheless, translation has never been an insurmountable hindrance and constitutes only an intellectual challenge the Humanities are most familiar with. Every individual competent in a second language thus becomes a crucial ambassador connecting different cultures over time and space.

\section{A Modern Perspective: Fontane}

One intriguing fairly modern example would be Theodor Fontane's (18191898) ballad "Die Brück' am Tay" (1879; The Bridge Spanning the Tay) in which the poet, drawing both from Shakespeare's Macbeth and a contemporary tragic accident affecting the famous new railroad bridge spanning the Firth-ofTay near Dundee in Scotland, ruminates upon the human hubris in face of the enormous forces of nature. The bridge seemed to be a miracle of modern technology at that time, but when the train crossed it on December 28, 1879, 
the storm gained such strength that the entire structure collapsed, resulting in the death of seventy-five people. Fontane reflects the pride in human ingenuity, but also reveals our limitations in front of the natural forces.

As the allegorical figures in the refrain emphasize over and over again, no human effort can achieve the desired result when the true power of the world around us is ignored. A modern example would be the deeply sobering account entitled Phi Phi Island: ein Bericht (2007), written by the Austrian author Josef Haslinger who, along with his family, would have almost drowned in the tsunami of 2004 and reflected in his text on their experiences under those terrifying and life-threatening circumstances.

\section{Part II: The Challenges of the Past in Our Own Time}

One of the critical issues in our own world today is the condition of women within society, and of the members of the LGBTQ community. The gender discourse, however, is not new at all, and can easily trace its origins back to the twelfth and thirteenth centuries. Marie de France, for instance, famous for her fables, lais, and hagiographical narratives (d. ca. 1200), was already deeply committed to the question of how women could find personal happiness within their feudal world. She composed numerous lais, above all, in which she explored women's destiny, especially as wives and young ladies who dream of marrying the man whom they love. Marriage and loyalty emerge as central themes in her texts that continue to appeal to modern audiences throughout the world (Kinoshita and McCracken 2012, Classen 2016b). She also sheds light on the issue of homosexuality ("Lanval") and incest ("Les deus amanz"), and explores how young individuals can navigate through a web of highly complicated social conditions that often stand in the way of achieving personal happiness ("Milun", "Yonec"). In fact, Marie's lais prove to be extraordinary insightful narratives in which cases of human conditions are examined, studied from a variety of perspectives, but all this always with the aim to realize fundamental values and ideals ("The Lais of Marie de France" 2018).

If we look for early feminists fighting for women's rights and causes, Christine de Pizan (1364-ca. 1430) immediately comes to our mind, even if she did not necessarily espouse quite the same values as our postmodern successors might do today (Margolis 2011, Classen 2016b). Of course, my point here is not to introduce individual writers of great significance at their time and to idolize them within their historical context, but to emphasize the timeless value of many of the pre-modern voices who continue to appeal to us today because of their bold visions and creative approaches in matters such as gender relationships. We could also draw on the rich body of medieval literature, philosophy, and theology where we can detect traces or even strong indications of toleration and tolerance, such as in the works of Wolfram von Eschenbach, Rudolf von Ems, Boccaccio, Ramon Llull, Nicholas of Cusa, or Sebastian Franck (Classen 2018c). 
The past has not simply faded away; the present can certainly learn in profound manner from the lessons left behind in those medieval and early modern texts, especially if we simply adapt them carefully to the current conditions and accept them as the bases for the critical examination of rather difficult or even dangerous situations separating or marginalizing people today because of their race, religion, or gender orientation. We have an enormous treasure trove available to reflect upon who we are, what we could turn into, and what to avoid in light of past experiences. Those literary laboratories allow us to carry out endless human experiments and to learn about many different potentials to realize our goals, dreams, and ideals.

A rather somber and depressing example would be war, whether the Thirty Years' War, the Napoleonic wars, the First World War, the Second World War, or our global fear of a possible Third World War (Jacob et al. 2018). There are many approaches to war possible, both historical, military, technological, political, and literary. Some might regard wars as necessary valves releasing human energy in its constant conflict with that of others. We could also point toward the high need of people to defend themselves against military aggressors. It would also be possible to identify wars as the outcome of technological developments, or of ideological, religious conflicts. At any rate, despite the fact that there is much literature glorifying war and male heroism, most writers and poets throughout time have voiced severe criticism and opposition to war, identifying it as the collapse of humanity and our cultural ideals ("War and Peace" 2011, Classen 2016c, Classen Forthcoming-b). While twentieth-century writers such as Ernst Jünger, Ernest Hemingway, or Erwin Dwinger still could idealize war as the ultimate medium for a man's self-fulfillment, the present situation with nuclear bombs having the potentiality of destroying humankind altogether, makes us view wars very differently today. However, this is not a new perspective, as we can observe in numerous medieval and early modern texts, maybe most famously by Erasmus of Rotterdam (1466-1536) who voiced harsh criticism of wars in a variety of writings ("About War and Peace" 2018).

We can now draw some preliminary conclusions in light of the wide gamut of examples listed above. It would be wrong to eliminate the historical differences and to claim that all people from throughout time have gone through the same experiences. Of course, the situations and conditions in the Middle Ages and the early modern age were very different from those in our own time. No one would naively claim that we could easily draw from premodern literature as a treasure trove of lived lives for us today. There were different kinds of fears, anxieties, norms, values, and ideals in the past, compared to our modern western world today. Nevertheless, if we accept that the fundamental struggles in the past continue to be of supreme importance and that those involved in them faced the same difficulties as we do now, we can return to three key concepts developed above: 1 . life is a tree, with its vertical and its horizontal dimensions; 2. life is a narrative, and via the endless concatenations we all participate, consciously or not, in the same discourse, searching, for instance, until today for true happiness and spiritual meaning; and 3. as people we are connected not only to those who live as our 
contemporaries, but also to those who were our predecessors and who will be our successors.

Crime and violence are maybe more contained today than in the past, but they explode in our societies many times just as well. The reasons might be somewhat different today, and our reactions to them are not quite the same as in the past. Nevertheless, both the medieval world and we today have established laws, rely on a legal and judicial system, and make every attempt, just as our predecessors did, to restrict violence and thus to establish peace. When Walther von der Vogelweide (d. ca. 1220), in his famous stanzaic poem "Ich saz ûf eime steine" (L 8.4, no. 27; I sat upon a boulder), appealed to his contemporaries to establish peace and justice before anything else, whereupon there might be the possibility to achieve the elusive goal of gaining both material wealth and public honor, and this combined with God's grace, he basically addressed the same issue that we face today under many different circumstances (von der Vogelweide 2003: p. 140, trans. on p. 141). The discourse continues, but at times it appears to be much easier to focus on older narratives and poems where we can examine the case in isolation and with a little more critical perspective without the personal impact.

\section{Part III: The Meaning of the Past, in Karl Jaspers's View}

From here I would like to turn to the ideas developed by Karl Jaspers (1883-1969), a German-Swiss intellectual who is famous for his deep influence on many fields of thought today, such as theology, history, psychiatry, philosophy, morality, and ethics. Jaspers almost became a victim of the Nazi regime, but he survived, and emerged as a major spokesperson of the German world, courageously addressing the issue of guilt, responsibility, morality, and ethics. At the end of the sixth episode of the BBC documentary series The Nazis: A Warning from History (1997), he was quoted as: "That which has happened is a warning. To forget it is guilt. It must be continually remembered. It was possible for this to happen, and it remains possible for it to happen again at any minute. Only in knowledge can it be prevented" (Jones 2011). Leaving most of the intellectual contributions by Jaspers aside, here I want to focus on his comments concerning history and its relevance for us today. Jaspers generally pursued a global perspective, trying to comprehend world history in its connectivity, but we can contend ourselves here with an analysis of how past and present interact with each other (Wallraff 1970, Olson 1979, Thornhill 2002, Bormuth 2006, Fuchs et al. 2014, Jaspers 2008).

Jaspers's Vom Ursprung und Ziel der Geschichte cannot be summarized and analyzed in all the necessary details here, especially because he is mostly concerned with establishing a universal perspective regarding the structure of world history, the schema of world history, the relationship between history and the modern sciences and technology, the possible avenues toward the future, the relevance of peace, the differences between ideological systems 
(socialism versus capitalism), and the role of faith (Jaspers 1949/2017) ${ }^{12}$. Jaspers did not believe in the global ideas of a perennial return of past structures without significant changes (Nietzsche), of an apocalyptic development (Spengler), of a cyclical movement of all history (Toynbee), or of an idealized future world without social classes (Marx); in short, he rejected the notion of human determinism and argued, instead, that the principles of individual freedom and personal responsibility would guide and steer all individuals toward their future. History offers possibilities, options, and each individual can choose to make the best use of them, or to reject or ignore them. In Kurt Salamun's words, "Die weitere Entwicklung hängt vom vernünftigen und verwantwortungsorientierten Handeln der einzelnen Menschen ab" (ed. Salamun, XIII; The further development depends on the rational and responsible actions of the individual people).

Jaspers underscored the central importance of faith as a projection by people that have to be understood in symbolic terms because each concept of God proves to be an effort to come to terms with transcendence that is always present but cannot be easily, if at all, identified by the human mind (204). Freedom emerges as the central hallmark of history, as Jaspers observes: "Der Widerhall aus der Geschichte, das Beschwingende im Umgang mit unseren Ahnen bis an den Ursprung des Menschengeschlechts ist ihr Suchen der Freiheit, wie sie Freiheit verwirklichten, in welchen Gestalten sie sie entdeckten und wollten. Wir erkennen uns wieder in dem, was Menschen vermochten und was sie aus ihrer geschichtlichen Wirklichkeit zu uns sagen" (205); [The echo of history, the energy resulting from the engagement with our ancestors down to the original beginning of humanity, is their search for freedom, is the realization how they achieved freedom, in what form they discovered it and wanted it. We recognize ourselves in what people were capable of doing and what they are telling us from their historical reality]. The past was not predetermined, and no predetermination rules of people in the present time; instead, everything depends on the individual's choice, the freedom that guides the individual toward his/her decisions (205).

Throughout time, people have always ruminated on the secrets of this world and have marveled about the potentiality that evolves all the time, especially because the world is the site of the tasks that people have to face as part of their lives (205). At the same time, for Jaspers the role of faith ruled supreme: "Die Geschichte ist der Gang des Menschen zur Freiheit durch die Zucht des Glaubens" (206); [History is the march of people toward freedom by means of the disciplinary forces of faith]. Subsequently, Jaspers carefully differentiates between tolerance and toleration, the latter being nothing but "Gleichgültigkeit" (206); [indifference], while the former is defined by the realization of the own limitations, also in matters of faith (206). Although humanity proves to be extremely diverse, all people go back to the same roots and share the same origins (206). The individual can grow and develop only

\footnotetext{
${ }^{12}$ Jaspers was strongly opposed to a deterministic world view and rejected such intellectuals as Arnold Toynbee, Oswald Spengler, and Karl Marx (see ed. Salamun, XIII-XIV).
} 
when there is faith in all people and their potentiality, which, in turn, can be traced back to a unified origin (206).

All human beings, because of their humanity, carry within them the basic instinct of tolerance, which opens fascinating perspectives toward the past where we can find, indeed, the origin of this discourse on tolerance. The world does not consist only of materiality, but is much more profoundly determined by spirituality (207), which thereby underscores the relevance of history as a staging ground for those experiments to find the pathway toward the spiritual dimension. Jaspers seriously doubts that the future development will see the rise of a completely secular world empire without any forms of faith. Despite the countless backslashes throughout history, there has always been a stream of individuals, carried by a deep faith, who moved humanity forward throughout time. Hope for the future would be realistic only then when "die vielfachen Glaubensgehalte frei bleiben in ihrer geschichtlichen Kommunikation ohne Einheit eines objektiven, allgemeingültigen Glaubensinhalts" (211); [the multiple concepts of faith remain free in their historical communication without being bound by the unit of one, objective, universally obligatory faith].

Subsequently, Jaspers turns more specifically to the role of history and insists that we need the past in order to understand ourselves because it represents our memory from which we all live (215). We must always remember that we are human beings, and we can do that only if we hold on to our own past. Naturally, crises have regularly characterized past epochs, and the present world, that is, the entire late nineteenth and twentieth century, hence also our own time today, would have to be identified as being in the clutches of a crisis. But human idealism can be traced even in the worst times, which makes the study of history to such an elementary task (216). In order to understand who we are, where we have come from, and where we might be heading we would need to know what the limits have been of all human history: "Was die Geschichte als Ganzes bedeutet, hören wir vielleicht am ehesten von ihren Grenzen her" (216); [What history means in its totality we might hear most likely from the borderlines]. This does not help, of course, to comprehend history at large in its universality, but the probing of meaning would constitute already the pathway toward a fundamental understanding of human existence. The essential aspect of history consists of the "Überlieferung durch Autorität und darin eine Kontinuität durch erinnernden Bezug auf das Vergangene" (217); [tradition through authority and in that the continuity through a remembering reference to the past].

Jaspers goes even one step further and claims that true history constitutes the events that are not squashed by time (217). Insofar as human beings will always be incomplete and will always strife for completion, they are not only in search of, but also in need of historicity: "Denn wir sind nicht die Gottheit, die richtet, sondern Menschen, die ihren Sinn öffnen, um Anteil zu gewinnen am Geschichtlichen, das wir daher, je mehr wir es begreifen, um so betroffener immer noch suchen" (217); [We are not the Godhead who is judging, but people who open up their minds to gain involvement in the historical process. The more 
we understand it, the more we'll be searching for it as a result of us being so affected].

History is, as Jaspers formulates, both being and self-consciousness (218). Our existence is framed by a constant coming and going, by decline and rebirth, and we all belong to the same process which is historical and not at all just horizontal in its development (219). All cultures are born, live, and ultimate experience their death as well (219), and ignoring this constant up and down would mean the ignorance of history, and hence the refusal to understand what really defines and determines human life. We are, as Jaspers emphasizes, both tradition and nature, both intimately interlaced with each other. While we develop as living creatures, we establish culture only through our historical awareness (220). Nature, such as our genetic code, remains the same all the time, whereas culture and tradition are always easily subject to loss and disappearance; history is highly unstable. For Jaspers, all life is deeply identified through a spiritual substance which is "erfüllt und klar durch die in der Geschichte sich vollziehende geistige Bewegung. In ihr geht sie Verwandlungen ein" (220); [fulfilled and transparent through the intellectual movement as it takes place through history]. Taking one step further, he then argues that the historical dimension is not identified by the actions of the individual in his or her temporal essence, but in the unique and irreplaceable being behind all life. Not the individual, but the universal aspect of reality filled with a spirit constitutes true history (224).

\section{Conclusion}

I break off at this point because Jaspers then increasingly turns to ethical, almost religious arguments correlating the universal being in history with love, the soul, and other transcendental components that might not serve our purposes enough in the present context. However, it still deserves to be noted that he concludes with the following thought: "Was wir als geschichtlich Besonderes zu eigen gewinnen, läßt uns voranschreiten zur Gesamtgeschichte als zu einem einzigen Individuum. Alle Geschichtlichkeit wurzelt im Grunde dieser einen umfassenden Geschichtlichkeit" (225); [That what we gain as a historically unique entity allows us to go forward toward universal history which is a unitarian individuum. All historicity is rooted in the ground of this one and all encompassing historicity]. But he then also comments that the meaning of history is the growth of an interconnectedness of meanings that bring together the entire world, based on a universal sense of oneness (242).

We recognize here, to return to my previously mentioned simple iconic image, the historical tree, the one living organism called human life which spreads out and grows both vertically from the past to the future and horizontally in an expansive way, staking its own ground here in this life, as a historical being.

Moreover, Jaspers places greatest emphasis on the presence of a historical spirituality that creates a universal network beyond all religious and ideological 
divides. This kind of tolerance, however, is only possible, as we have already seen above, if we all recognize and accept the historical roots of our own values and ideals, behind which always rests a commonly shared humanity. The huge corpus of pre-modern literature and historical and religious documents, for instance, allows us to tap into this enormous reservoir of lived experiences, each one of them having contributed to the growth of the root and then the trunk of the metaphorical tree.

Of course, cynical critics would easily dismiss most of those thoughts and point only toward the overarching need to develop new technologies, to establish innovative production sites, and to set up research labs for future machines, robots, computers, and the like. The ever-growing world population needs to be fed, so we need new drought resistant crops, for instance, and should not waste our time with sophisticated, esoteric reflections on our origins and the essence of human existence. As a matter of fact, we have to accept those demands all by themselves without any restrictions since we live today and evolve together as a society into a new generation challenged by external, material demands.

Nevertheless, as both Jaspers's theoretical reflections and the numerous literary examples introduced above have clearly indicated, human life does not simply consist of productivity and consumption. We are not machines, but living creatures with feelings, ideals, dreams, values, and hopes. Individual happiness is not possible within the exclusive framework of a capitalistic society. Already Boethius recognized this profound insight shortly before his death when he composed his Consolatio Philosophiae in 525. What poet or philosopher in the following centuries would not have agreed with him, as countless courtly love poems, grail romances, heroic poems, lais, tales, moeren, religious plays, fables, and many texts in other genres have strongly confirmed.

A great example, to conclude these ruminations, would be the late medieval alliterative romance, Sir Gawain and the Green Knight (ca. 1370) (Cooper and Harrison 2014) ${ }^{13}$. Apart from the narrative excitement based on the wonders, magic, grizzly beheading, sexual temptations, tricky wager over hunting exploits, the anonymous author also addressed a fundamental issue in human life, or rather aimed at it overall, that is, how to maintain one's honor and to enjoy happiness in face of the greatest challenges. Gawain could have easily given in to the sexual offers by Bertilaks's wife; he could have easily fled from that mysterious site in the forest and avoided the Green Chapel, as the servant encourages him to do. He had already lied about the green belt and did not hand it over to Bertilak as part of their agreement concerning the wager. But he is subsequently only slightly punished with a small neck wound, and Bertilak immediately forgives him because he understands fully that Gawain only wanted to live and tried to believe in the magic of the belt.

In short, as we can learn at the end, the greatest knight of them all has slightly failed, and Gawain feels deep shame, but everyone at King Arthur's court only laughs about this in sympathy and demonstrates their empathy with

\footnotetext{
${ }^{13}$ There are countless critical studies on this alliterative romance; see, for instance, Burrow (1965/1966); Barron (1980).
} 
his suffering and tribulations. In fact, they all put on a green belt thereupon as a sign of the humility which truly behooves a knight. All this, however, directly speaks to us today since we are also prone to fail, since we also want to live and are mostly prepared to pay any price to achieve that goal. But there is, after all, the ultimate goal of maintaining one's honor, and Gawain knows only too well that he has not been able to observe every aspect of the wager. We are, as this alliterative romance plainly tells us, human beings, weak in many respects, but also spiritual people who continue to strive for honor even if we might never quite achieve it or cannot hold on to it.

This is the history of the human existence, it is rooted in ancient experiences, and when we want to march forward, we must at first make sure that we know how to look backwards to make out the markers of our path toward the future. The literary example serves as an experiment or a laboratory of human experiences, good and bad, and whenever we examine literary, or philosophical texts, we are invited to consider extreme situations that allow us to reflect upon ourselves without necessarily being forced to face the same conditions. We have always accepted that the genre of fairy tales serves our goals of teaching children fundamental values, and the consequence would simply be that good literary texts, however defined, serve equally well for us as human individuals to comprehend the critical issues in our existence and come to terms with them in a constructive fashion. Jaspers would have certainly agreed with this assessment, although his philosophical reflections are much more transcendental than my own concrete examples and arguments.

\section{References}

About War and Peace: The pamphlets of Erasmus of Rotterdam (2018). From Latin by H-J Pagel, WF Stammler, W Stingl. Commented by H-J Pagel. Edited by WF Stammler, H-J Pagel, T Stammen. Library of historical memorabilia. Essen: Alcorde Verlag.

An SA, Budkeev SM, Usanova AL (2018) "Life as a Literary Text: Narrative in the Autobiographical Paintings of D. Galanin and Memoirs of the People's artist M. Budkeev". Astra Salvensis 6(12): 513-522.

Armstrong A, Strietman E (2017) (ed.) The Multilingual Muse: Transcultural Poetics in the Burgundian Netherlands. Cambridge: Legenda.

Barron WR (1980) Trawthe and treason: The Sin of Gawain Reconsidered: A Thematic Study of Sir Gawain and the Green Knight. Publications of the Faculty of Arts of the University of Manchester, no. 25. Manchester: Manchester University Press.

Bess M, Pasuka DW (2018) (ed.) Posthumanism: The Future of Homo Sapiens. Farmington Hills, MI: Macmillan Reference.

Bikont A (2015) The Crime and the Silence: Confronting the Massacre of Jews in Wartime Jedwabne. Translated by Alissa Valles. New York: Farrar, Straus and Giroux.

Blažek P (2018) (ed.) Sacramentum Magnum: Die Ehe in der mittelalterlichen Theologie. Le mariage dans la théologie médiévale. Marriage in Medieval Theology. Münster: Aschendorff. 
Bloom H (1994) The Western Canon: The Books and School of the Ages. New York: Harcourt Brace.

Bormuth M (2006) Life Conduct in Modern Times: Karl Jaspers and Psychoanalysis. Philosophy and Medicine, no. 89. Dordrecht: Springer.

Bradley EH (2018) "The Practical Humanities". Inside Higher Education. Retrieved from https://ces.to/NjUwWR.

Brecht M (2008) Johann Valentin Andreae, 1586-1654: eine Biographie. Göttingen: Vandenhoec \& Ruprecht.

Brockmeier J, Carbaugh DA (2001) Narrative and Identity: Studies in Autobiography, Self and Culture. Studies in Narrative, no. 1. Amsterdam and Philadelphia, PA: John Benjamins Publications.

Brown B (2017) Braving the Wilderness: The Quest for True Belonging and the Courage to Stand Alone. London: Vermilion.

Bruner J (1988) "Research Currents: Life as Narrative". Language Arts 65(6): 574-583

Burrow JA (1965/1966) A Reading of Sir Gawain and the Green Knight. London: R. and K. Paul.

Busch N, Reich B (2014) (ed.) Vergessene Texte des Mittelalters (Forgotten texts of the Middle Ages). Stuttgart: S. Hirzel Verlag.

Chinca M, Reuvekamp-Felber T, Young C (2006) (ed.) Mittelalterliche Novellistik im europäischen Kontext: kulturwissenschaftliche Perspektiven (Medieval novellistry in a European context: cultural-scientific perspectives). Journal of German Philology, Supplements, 13. Berlin: Erich Schmidt.

Clark Kee H (1997) The Cambridge Companion to the Bible. Cambridge and New York: Cambridge University Press.

Classen A (Forthcoming-a) "Multilingualism and Multiculturalism in the Pre-Modern Age: Medieval Welsh and Icelandic Literature in a Literature Survey Course. Interdisciplinary Approaches on a Pan-European Level". Leuvense Bijdragen.

Classen A (Forthcoming-b) "Massive Death and Apocalyptic Experiences from the OHG 'Hildebrandslied' to the Nibelungenlied, Kudrun, and Heinrich Wittenwiler's Ring. Poetic Reflections in Medieval German Literature on Tragic Outcomes and Armageddon". In E Hintz, S Pincikowski (Eds.), The Endtimes in Premodern Germany: The Apocalypse, Last Judgment and Evil in a Literary Culture.

Classen A (2018a) "STEM and Teaching German Language and Literature with an Interdisciplinary Approach: Eighteenth-Century Reports by German Jesuit Missionaries in the German Classroom". Die Unterrichtspraxis 51(1): 53-62.

Classen A (2018b) "The Human Quest for Happiness and Meaning: Old and New Perspectives: Religious, Philosophical, and Literary Reflections from the Past as a Platform for Our Future: St. Augustine, Boethius, and Gautier de Coincy". Athens Journal of Humanities \& Arts 5(2): 179-206.

Classen A (2018c) Toleration and Tolerance in Medieval and Early Modern European Literature. Routledge Studies in Medieval Literature and Culture, no. 8. New York and London: Routledge.

Classen A (2016a) "The Meaning of Literature and Literature as Meaning-A Productive Challenge of Modern Times from the Middle Ages". Humanities 5(2): 24. Retrieved from https://ces.to/fFYW9r.

Classen A (2016b) Reading Medieval European Women Writers: Strong Literary Witnesses from the Past, pp. 83-118. Frankfurt a. M.: Peter Lang.

Classen A (2016c) "Eine einsame Stimme für den Frieden im Mittelalter: Der erstaunliche Fall von Kudrun" (A lonely voice for peace in the Middle Ages: The amazing case of Kudrun). Thalloris 1: 69-90. 
Classen A (2015a) "Medieval Studies within German Studies: The Nibelungenlied and Hartmann von Aue's Der arme Heinrich)". In R Halverston, CA Costabile Heming (Eds.), Taking Stock of German Studies in the United States: The New Millennium, pp. 52-67. Studies in German Literature, Linguistics, and Culture. Rochester, NY: Camden House.

Classen A (2015b) (ed.) Handbook of Medieval Culture: Fundamental Aspects and Conditions of the European Middle Ages, 3 vols. Berlin and Boston: Walter de Gruyter.

Classen A (2013a) "Einleitung” (Introduction). In A Classen, E Parra-Membrives (Eds.), Literatur am Rand: Perspektiven der Trivialliteratur vom Mittelalter bis zum 21. Jahrhundert (Random literature: perspectives on trivial literature from the Middle Ages to the 21st century). Popular Fiction Studies, no. 1, pp. 7-32. Tübingen: Narr Verlag.

Classen A (2013b) "Friendship, Death, and Boethian Philosophy in the High Middle Ages: The Meaning of the Past for Our Present and Future. With a Special Focus on Lawrence of Durham's Consolatio (1141) and Aelred of Rievaulx's De Spirituali Amicitia (1164-1167)". Medieval Perspectives 28: 9-31.

Classen A (2012) "Gutes Leben und guter Tod von der Spätantike bis zur Gegenwart: Ein philosophisch-ethischer Diskurs über die Jahrhunderte hinweg" (Good life and good death from late antiquity to the present: a philosophical-ethical discourse over the centuries). In A Classen (Eds.), Gutes Leben und guter Tod von der Spätantike bis zur Gegenwart: Ein philosophisch-ethischer Diskurs über die Jahrhunderte hinweg (Good life and good death from late antiquity to the present: a philosophical-ethical discourse over the centuries). Theophrastus Paracelsus Studies, no. 4, pp. 1-109. Berlin and New York: Walter de Gruyter.

Classen A (2011a) "The Torturous and Random Process of the Canonization in Literary History from the Middle Ages to the Present. The Case of Erasmus Widmann as an Example - The Victimization of a Poet Oddly Situated between Epochs, Cultures, and Religions”. Studia Neophilologica 83(1): 94-103.

Classen A (2011b) "Friends and Friendship in Heroic Epics: With a Focus on Beowulf, Chanson de Roland, the Nibelungenlied, and Njal's Saga". Neohelicon 38(1): 121-139.

Classen A (2000) "The Bloody Battle Poem as Negative Examples: The Argument against Blood Feud and Images of Peaceful Political Negotiations in German Heroic Poetry". Amsterdamer Beiträge zur älteren Germanistik 53: 123-143.

Classen A (1993) "Kanon und Kanon-Transgression. Betrachtungen zur mittelhochdeutschen Dichtung. Zugleich eine Einleitung" (Canon and Canon Transgression. Reflections on Middle High German poetry. At the same time an introduction). In A Classen (Eds.), Canon and Canon Transgression in Medieval German Literature. Göppinger works on German studies, no. 573, pp. 1-36. Göppingen: Kümmerle.

Clements RC, Gibaldi J (1977) Anatomy of the Novella: The European Tale Collection from Boccaccio and Chaucer to Cervantes. The Gotham Library of the New York University Press. New York: New York University Press.

Comenius JA (1992) Auf den Spuren des Comenius: Texte zu Leben, Werk und Wirkung (In the footsteps of Comenius: Texts on life, works and effects), edited by $\mathrm{K}$ Grossmann, H Schröer. Göttingen: Vandenhoeck \& Ruprecht.

Cooper H, Harrison K (2014) (ed.) Sir Gawain and The Green Knight. Oxford World's Classics. Oxford: Oxford University Press.

Dafoe N (2016) The Misdirection of Education Policy: Raising Questions about School Reform. Lanham, MD: Rowman \& Littlefield. 
David P (1992) Story-Telling Techniques in The Arabian Nights. Leiden: Brill.

Davis RC, Finke L (1989) (ed. \& intro) Literary Criticism and Theory: The Greeks to the Present. New York and London: Longman.

Dinzelbacher P (1993/2008) (ed.) Europäische Mentalitätsgeschichte: Hauptthemen in Einzeldarstellungen (European history of mentality: main topics in individual representations). Stuttgart: Alfred Kröner.

Dreifuss H (2017) Relations Between Jews and Poles During the Holocaus: The Jewish Perspective. Translated by Ora Cummings. Jerusalem: Yad Vashem.

Farré L (1953) Vida y pensamiento de Jorge Santayana (Life and thought of Jorge Santayana). Madrid: Ediciones "Verdad y Vida".

Foucault M (1972) The Archaeology of Knowledge and the Discourse on Language. Translated by AM Sheridan Smith. New York: Pantheon Books.

Fuchs T, Breyer T, Mundt C (2014) (ed.) Karl Jaspers' Philosophy and Psychopathology. New York: Springer.

Ghanim D (2018) The Sexual World of the Arabian Nights. Cambridge: Cambridge University Press.

Gleason DW (2018) "The Humanities Meet STEM: Five Approaches for Humanists". Arts and Humanities in Higher Education. Retrieved from https://ces.to/YrPBzS.

Gottcent JH (1979) The Bible as Literature. Boston, MA: Hall.

Grubmüller K (2006) Die Ordnung, der Witz und das Chaos: Eine Geschichte der europäischen Novellistik im Mittelalter: Fabliaux - Märe - Novelle (The Order, the Joke and the Chaos: A History of European Novellistry in the Middle Ages: Fabliaux - Märe - Novelle). Tübingen: Max Niemeyer.

Hatch JA, Wisniewski R (1995) Life History and Narrative. Qualitative Studies Series, no. 1. London and Washington, DC: Falmer Press.

Hunt L (2018) History: Why it Matters. New York: John Wiley \& Sons.

Jacob F, Shaw JM, Demy T (2018) (ed.) War and the Humanities: The Cultural Impact of the First World War. War (Hi) Stories, no. 2. Paderborn: Ferdinand Schöningh.

Jaspers K (2008) Geschichtliche Wirklichkeit: mit Blick auf die Grundfragen der Menschheit (Historic Actuality: in View of Fundamental Problems of Mankind). Würzburg: Königshausen \& Neumann.

Jaspers K (1949/2017) Vom Ursprung und Ziel der Geschichte (From the origin and goal of the story), edited by K Salamun. Karl Jaspers, Complete Edition, I/10 \& Basel: Schwabe Verlag.

Jansen KL (2017) Peace and Penance in Late Medieval Italy. Princeton, NJ: Princeton University Press.

Jenkins K (1999) Why History?: Ethics and Postmodernity. London and New York: Routledge.

Jones I (2011) "The Nazis: A Warning from History". Off the Telly. Archived from the original on 23 November 2011. Retrieved 10 June 2013; here quoted from https://ces.to/SkEuG8.

Kinoshita S, McCracken P (2012) Marie de France: A Critical Companion. Gallica, no. 24. Cambridge: D.S. Brewer.

Knauer B (1997) (ed.) Das Buch und die Bücher: Beiträge zum Verhältnis von Bibel, Religion und Literatur (The book and the books: Contributions to the relationship between the Bible, religion and literature). Würzburg: Königshausen \& Neumann.

Krüger L (2005) Why Does History Matter to Philosophy and the Sciences?: Selected Essays. Sources and Studies on Philosophy, no. 66. Berlin and New York: Walter de Gruyter. 
Lang B (2019) Religion und Literatur in drei Jahrtausenden: Hundert Bücher (Religion and Literature in Three Millennia: One Hundred Books). Paderborn: Ferdinand Schöningh.

MacMullen R (2014) Why Do We Do What We Do?: Motivation in History and the Social Sciences. Warsaw: De Gruyter Open.

Margolis N (2011) An Introduction to Christine de Pizan. Gainesville, Tallahasse: University Press of Florida.

McAfee CB (1998) The Greatest English Classic: A Study of the King James Version of the Bible and its Influence on Life Literature. Charlottesville, VA: University of Virginia Library.

Murphy D (1995) Comenius: A Critical Reassessment of His Life and Work. Blackrock, Co. Dublin: Irish Academy Press.

Norton D (2000) A History of the English Bible as Literature. Cambridge and New York: Cambridge University Press.

Nussbaum MC (2012) Not for Profit: Why Democracy Needs the Humanities. Public Square Book Series. Princeton, NJ, and Woodstock: Princeton University Press.

Olson AM (1979) Transcendence and Hermeneutics An Interpretation of the Philosophy of Karl Jaspers. Studies in Philosophy and Religion, no. 2. Dordrecht: Springer.

Ouyang W-C, van Gelder GJ (2005) (ed.) New Perspectives on Arabian Nights: Ideological Variations and Narrative Horizons. Oxford and New York: Routledge.

Pleshakova V (2009) The Importance of Teaching Humanities in Higher Education Institutions: in Defense of Liberal Arts Education. PhD dissertation, University of Vermont. Retrieved from https://ces.to/fgOoNO.

Pohl W (2018) The Avars: A Steppe Empire in Central Europe, 567-822. Ithaca, NY, and London: Cornell University Press.

Polonsky A (1990) (ed.) "My Brother's Keeper: Recent Polish Debates on the Holocaust". London: Routledge.

Sallis E (1999) Scheherazade Through the Looking Glass: The Metamorphosis of The Thousand and One Nights. New York: Routledge.

Schiffrin D, De Fina A, Nylund A (2010) Telling Stories: Language, Narrative, and Social Life. Washington, DC: Georgetown University Press.

Sharman JC (2019) Empires of the Weak: The Real Story of European Expansion and the Creation of the New World Order. Princeton, NJ: Princeton University Press.

Simonton DK (1994) Greatness: Who Makes History and Why. New York: Guilford Press.

Sinaiko HL (1998) Reclaiming the Canon: Essays on Philosophy, Poetry, and History. New Haven, CT: Yale University Press.

Sorabji R (2006) Self: Ancient and Modern Insights About Individuality, Life, and Death. Chicago: University of Chicago Press.

The Arabian Nights: A Norton Critical Edition (2010). Translated by H Haddawy, edited by M Mahdi, and selected and edited by D Heller-Roazen, Edition 1. New York: W. W. Norton \& Company.

The Lais of Marie de France: Text and Translation (2018). Edited and translated by CM Waters. Peterborough, Ont.: Broadview.

Thornhill CJ (2002) Karl Jaspers: Politics and Metaphysics. Routledge Studies in 20th Century Philosophy, no. 11. London and New York: Routledge.

Tormey W (2018) "The Journey within the Journey: Catabasis and Travel Narrative in Late Medieval and Early Modern Epic". In A Classen (Eds.), Travel, Time, and Space in the Middle Ages and Early Modern Time: Explorations of Worldly 
Perceptions and Processes of Identity Formation, Fundamentals of Medieval and Early Modern Culture, no. 22, pp. 585-621. Berlin and Boston: Walter de Gruyter.

Truitt ER (2015) Medieval Robots: Mechanism, Magic, Nature, and Art. The Middle Ages Series. Philadelphia, PA: University of Pennsylvania Press.

Verene DP (2018) The Art of Humane Education. Ithaca, NY: Cornell University Press. von der Vogelweide W (2003) The Single-Stanza Lyrics. Edited and translated with introduction and commentary by F Goldin. New York and London: Routledge.

von Kutschera F (2019) Der Weg der westlichen Philosophie (The way of Western philosophy). Paderborn: Mentis.

Wallraff CF (1970) Karl Jaspers. Princeton Legacy Library. Princeton: Princeton University Press.

War and Peace: Critical Issues in European Societies and Literature, 800-1800 (2011), edited by A Classen, N Margolis. Fundamentals of Medieval and Early Modern Culture, no. 8. Berlin and New York: Walter de Gruyter.

Wolff-Powęska A, Forecki P (2013) (ed.) Reconstructing Memory: The Holocaust in Polish Public Debates. Translated by Marta Skowronska. Studies in History, Memory and Politics, no. 5. Frankfurt a. M.: Peter Lang.

Wippel JF (2011) The Ultimate Why Question: Why is There Anything at all Rather than Nothing Whatsoever? Washington, DC: Catholic University of America Press.

Wineburg S (2018) Why Learn History (When It's Already on your Phone). Chicago and London: The University of Chicago Press. 